\title{
EVROPSKÁ UNIE A EURO: RISKANTNÍ EXPERIMENTOVÁNÍ S EVROPOU
}

\section{Václav Klaus*}

Fatální nepochopení skutečného, jakýmikoli siláckými výroky politiků neodstranitelného problému Evropské unie a eura přetrvává. Tento problém je důsledkem toho, co bylo těmto institucím už při jejich zrodu dáno do vínku, co je jejich vrozenou vadou, jejich definiční charakteristikou. Vše pokračuje bez sebemenší změny i přes dostatečně zřetelně viditelné signály z reálného světa jakými jsou: $(i)$ dlouhotrvající evropská ekonomická stagnace (řada zemí EU se dodnes nedostala na úroveň předkrizového roku 2007); (ii) evidentní zaostávání Evropy oproti rychle rostoucímu ,zbytku světa“, zejména Asii; (iii) dluhová krize nemalého počtu členských států eurozóny, zejména $\mathrm{v}$ jejím jižním křídle; (iv) trvale vysoká míra nezaměstnanosti; (v) chaos kolem migrace; (vi) neschopnost vypořádat se s rozhodnutím jedné členské země opustit EU; (vii) z ekonomického pohledu neobhajitelná energetická politika atd.

Tyto signály ukazují, že jak Evropská unie, tak jeden z jejich nejvýznamnějších výhonků - euro - přinášejí efekty úplně jiné, než jaké by podle záměrů svých tvůrců, propagátorů a apologetů přinášet měly.

Mezera mezi propagandou ovlivněnými očekáváními a realitou není neznámým fenoménem. Při studiu ekonomiky komunistické éry jsme mnozí pochopili, že jednou věcí byl hypotetický, normativní ideál centrálně plánované ekonomiky a úplně jinou věcí byla realita ekonomiky sovětského typu. Ta se chovala jinak, než jak to předpokládal a požadoval onen normativní model. Současná evropská realita naznačuje, že se obdobně velká mezera vytvořila i mezi realitou EU (a eurozóny) a jejím normativním modelem (často hovořím o tzv. expectations-reality gap).

Bez ohledu na to, bylo-li to tak původně zamýšleno a veřejně deklarováno, nebo zda se to tak vyvinulo postupně až v průběhu integračního procesu, Evropská unie (i její obě předcházející institucionální formy - EHS a ES) ve skutečnosti byla a je:

1. pokusem zbavit se $\mathbf{v}$ Evropě tradiční, historií prověřené, základní konstitutivní entity jak vnitrostátního, tak mezinárodního uspořádání westfálského typu, kterou je národní, či na bázi dominantního národa vytvořený stát. Právě díky (zejména) tomuto uspořádání nastal historicky unikátní rozmach Evropy a její vyčlenění se - politicky, ekonomicky, ale i kulturně a civilizačně - od zbytku světa. Právě ted' se této obrovské výhody bohužel zbavujeme.

Komplementární k tomu je úsilí nahradit stát uměle vytvořenou celokontinentální entitou, která má být alternativním - a podle dogmat ideologie multikulturalismu - kvalitativně lepším zdrojem identity obyvatel evropského kontinentu. Paralelním cílem

* Václav Klaus (office@institutvk.cz), Institut Václava Klause, o.p.s.

Text je zkrácenou verzí projevu autora na Komenského univerzitě v Bratislavě 23. března 2017. 
je - likvidací malých států - vytvořit velmoc schopnou být svou velikostí významným a respektovaným hráčem $v$ celosvětovém měřítku;

2. pokusem o odstranění hranic usnadnit v Evropě pohyb lidí, zboží, služeb a kapitálu. Masivní podporou pohybu lidí mimo území jejich původních států se mělo přispět $\mathrm{k}$ vytváření - v minulosti fakticky neexistující (pouze ex post postulované a normativně proklamované) - evropské identity. Ta identita se měla dotvářet podporou migrace uvnitř Evropy. ${ }^{2}$

Původně snad bylo záměrem pomocí integrace přispět i ke zvyšování ekonomického blahobytu, nikoli však úsilím o zvýšení efektivnosti ekonomického systému, nýbrž rozšiřováním velikosti trhu. Převažovala víra, že úspory z rozsahu více než vyváží ztráty ze zátěže, kterou přináší stále více nabobtnávající sociální stát, téměř geometrickou řadou se množící environmentalistická omezení svobody lidských aktivit a celková, zcela neúnosná přeregulovanost ekonomiky;

3. pokusem zajistit $\mathbf{v}$ Evropě přesun maxima rozhodování na centrální, nejlépe celokontinentální úroveň, nebot' různá selhání trhu a zejména všechny negativní spillover efekty jsou považovány za odstranitelné jedině zesílenou centrální regulací. Je to postaveno na nedůvěře $\mathrm{k}$ trhu a na představě, že v ekonomických aktivitách dominují externality nad ,internalitami“, resp. na tezi, že boj s externalitami je mnohem důležitější než starání se o systémové předpoklady racionálního chování ekonomických subjektů, tedy než starání se o trh;

4. jeden z klíčových prvků evropské unifikace, euro, byl a je nezodpovědným a riskantním pokusem abstrahovat od faktické heterogenity evropského ekonomického prostoru a je ambicí toto území uměle homogenizovat vytvořením jednotné evropské měny. Vedlejším cílem bylo vytvořit „,velkou“ měnu a touto konkurovat v minulosti se prosadivším světovým měnám. Euro nebylo a není primárně ekonomickým projektem, který byl - spolu se Schengenem - zamýšlen jako účinný př́íspěvek ke konečné likvidaci národních států.

Ve věci eura již bylo vše řečeno. Skoro před 20 lety jsem na konferenci v Lucemburku řekl, že ,,podmínky pro úspěšnou měnovou unii jsou mikroekonomické a nemají nic společného s makroekonomickými kritérii formulovanými v Maastrichtu“ (Klaus, 1998). Zdůraznil jsem, že přínosy obchodu jsou vázány na existenci zóny volného obchodu a celní unie a že v podstatě nesouvisí s měnovou unifikací, že „není možné bez nepř́ijemných následků udělat z jedné významné ekonomické proměnné veličiny konstantu“ (tamtéž). Varoval jsem, že když se zafixuje jedna veličina - měnový kurz - musí se začít hýbat veličiny jiné, zejména tím vznikne potřeba rozsáhlých mezistátních finančních transferů, protože ,náklady a výnosy měnové unie nebudou rovnoměrně rozděleny mezi její jednotlivé členy“ (tamtéž).

Bez uvědomění si a domyšlení těchto čtyř definičních charakteristik současné verze evropské integrace a bez eventuální připravenosti je opustit, upravit, zrevidovat nemá sebemenší smysl diskutovat jakékoli dílčí technicko-organizační či

2 Když ani to nestačilo, byl dán impulz k rozředění národních států migrací ze zemí mimo Evropu. 


\section{legislativně-ekonomické aspekty současné EU. Nemá smysl diskutovat ani návrhy případných parciálních změn.}

Pokusím se možné důsledky a souvislosti mnou výše uvedených čtyř definičních charakteristik unifikační verze evropské integrace rozvést trochu podrobněji:

ad 1: Jako první jsem uvedl rozbíjení westfálského uspořádání Evropy, oslabování či úplné potlačování národních států a vytváření nadnárodní, celokontinentální entity. Stále opakovaná teze, že je to potřebné pro to, aby byly v Evropě odstraněny války, je neudržitelná. Druhou světovou válku nezpůsobil národní stát, ale Hitler a jeho nacistická ideologie. Hitlera ostatně nakonec porazily právě a jedině národní státy (a ne nadnárodní instituce) a jejich schopnost mobilizovat své, svým vlastenectvím motivované občany k obraně států, které považovali za své vlastní.

Oslabování a vyprazdňování národních států (a paralelně s tím jdoucí proces zesilování evropské centralizace) v Evropě potlačuje demokracii. Ta vyžaduje autentický demos (politický lid) a ten - jak ukázala historie - mimo národní stát nemůže existovat. Unifikační proces proto vede k dedemokratizaci Evropy, ke vzniku postdemokratické společnosti (nejenom k tomu, co se eufemisticky nazývá demokratický deficit). Na kontinentální úrovni a v impériích a ř́íších demokracie existovat nemůže.

ad 2: Další, mnou výše zmíněnou ambicí evropské integrace bylo vytvořit velký ekonomický prostor, velký trh, což je v principu blahodárné. Důsledkem vzniku velkého otevřeného prostoru, prostoru bez hranic, i důsledkem zvýšené mobility lidí je rozbíjení národní identity a posilování identity evropské. To je - pro dnešní evropské elity - žádoucím vedlejším efektem.

Úspory z rozsahu v ekonomice existují, ale v reálném světě vysoce regulovaných trhů mají své limity a svá omezení. Těmi jsou disefekty plynoucí z narůstající vysoce centralizované regulace trhu. Významným disefektem je i nucená harmonizace neboli zbavování se systémové konkurence (dané odlišností ekonomických a sociálních systémů v jednotlivých zemích, což v minulosti směřovalo k prosazování se systému nejlepšího). O důsledcích zbytečné centralizace toho víme díky komunismu dost.

Likvidace hranic má ale ještě další nepř́ijemné účinky, které byly po celá desetiletí díky nepromyšlenému a nezodpovědnému propagování Schengenu zcela opomíjeny. Žretelně se projevily až při zrodu masové migrace 3 . Ekonomové musí rezolutně odmítnout falešné teze o migrantech jako o žádoucím př́livu pracovních sil, nebot' tito migranti nepřicházejí do Evropy jako pracovní síly a navíc máme v Evropě pracovních sil dostatek (v EU je více než 20 miliónů nezaměstnaných).

Dnešní masová migrace destabilizuje Evropu politicky, ekonomicky i civilizačně-kulturně a ke vzniku oné kýžené evropské identity v žádném případě nepřispívá, naopak ji oslabuje.

ad 3: Odpůrci trhu, a těmi jsou v drtivé většině evropští politici a je obklopující fellow travelers (evropská byrokracie, evropská média a akademici), bojují s trhem zveličováním defektů - či selhání - trhu (a zcela zapomínají na ještě daleko větší defekty

3 Širši pohled na tuto problematiku je obsažen v knize Klause a Weigla (2015). Řadu významných aspektů tohoto problému rozebírá též Břicháček (2016). 
státu). Ekonomové by měli říci zcela rezolutně, že externality v ekonomické aktivitě nedominují a že je jen velmi málo - svými důsledky významných - externalit, které se projevují i na celokontinentální úrovni. Několik dopravních tahů a produktovodů (ropovodů a plynovodů) snad opravdu má kontinentální povahu, ale - za prvé - vznikaly i bez EU (Orient expres, letecké spoje) a - za druhé - i ted' jsou v EU předmětem bezskrupulózní politiky velkých evropských hráčů (viz debata o severní či jižní větvi plynovodu), nikoli úsilím o maximalizaci ekonomického efektu pro občany jednotlivých evropských zemí.

Externality bývají postulovány jako významný důvod pro hledání celoevropských řešení. Musíme trvat na tom, že je sice koncept externalit nesmírně užitečným instrumentem ekonomické analýzy, ale že se může stát i velmi nebezpečným způsobem, jak ekonomickou argumentaci zcela torpédovat. A právě to se - zejména v souvislosti s argumentací environmentalistů - v současnosti v Evropě děje.

ad 4: Již v 90. letech, tedy před vznikem eura, mne vždy fascinovalo $(i)$ jednak podceňování faktické heterogenity evropských ekonomik a (ii) víra v to, že integrační (a zejména unifikační) proces povede k rychlé homogenizaci ekonomik a ne-li, pak aspoň $\mathrm{k}$ vytvoření politické unie, která bude důsledky této heterogenity fiskálními transfery solidárně kompenzovat.

Věcné argumenty v těchto diskusích nikdy nepůsobily. To, že je jih Itálie přes 150 let trvající politickou unií této země ekonomicky úplně jiný než italský sever, nehrálo a nehraje v představách Italů (a dalších Evropanů) o EU žádnou roli. To, že byla měnová unifikace Německa neuvěřitelně nákladným procesem, také ne (více Klaus [2007]). To, že Řecko před vstupem do eurozóny muselo po celá desetiletí opakovaně devalvovat svou drachmu, zatímco Německo stejně opakovaně, skoro v pravidelných intervalech, svou marku revalvovat, také ne. Problém není ani v Řecku ani v Německu, ale v chybné konstrukci eura.

Uplynulé desetiletí, zejména období od krize let 2008-2009, prokázalo, že členské státy eurozóny identické nejsou a že žádná měnová unie (a z ní vyplývající společná měna) neškodná a neutrální není. Peníze nejsou neutrální (zejména v krátkém a středním období), a proto ani jejich cenu - měnový kurz a úrokové sazby - nelze beztrestně politicky manipulovat. Zdá se mi, že měl pravdu raný Mundell (1961) a že se mýlil pozdní Mundell (1997, 2012), když začal obhajovat euro jako vhodný prvek evropské integrace.

\section{Literatura}

Břicháček, T. (2016). Unie ve víru migrační krize. Praha: Institut Václava Klause. ISBN 978-80-7542-023-7.

Klaus, V. (1998). European Monetary Union: Its Economic and Political Interdependencies. Přednáška na konferenci The Euro as a Stabilizer in the International Economic System Lucemburk.

Klaus, V. (2007). Komparative Analyse der Transformation im Multavialand und Albisland. Přednáška na Technické univerzitě Drážd’any. 
Klaus, V., Weigl, J. (2015). Stěhování národů. Praha: Olympia. ISBN 978-80-7376-422-7.

Mundell, R. A. (1961). A Theory of Optimum Currency Areas. American Economic Review, 51(4), 657-665.

Mundell, R. A. (1997). Updating the Agenda for Monetary Union, in Blejer, M. I., ed., Optimum Currency Areas, Washington, DC: IMF, pp. 29-50. ISBN 1-55775-652-X.

Mundell, R. A. (2012). The European Fiscal Reform and the Plight of the Euro. Global Finance Journal, 23(2), 65-76, https://doi.org/10.1016/j.gfj.2011.10.009 